Genet i c defi ci ency of carniti ne/organi $c$ cat i on transporter 2 ( sl c22a5) is associ at ed wi th al tered ti ssue di stribution of its substrate pyrilamine in mice

\begin{tabular}{|l|l|}
\hline 著者 & $\begin{array}{l}\text { Kat o Sayaka, Kat o Yuki o, Nakamur a Tadakat su, } \\
\text { Sugi ur a Tomoko, Kubo Yoshi yuki, Deguchi } \\
\text { Yoshi har u, Tsuj i Aki r a }\end{array}$ \\
\hline $\begin{array}{l}\text { j our nal or } \\
\text { publ i cat i on t i t l e }\end{array}$ & Bi ophar naceut i cs and Drug Di sposi ti on \\
\hline vol une & 30 \\
\hline number & 9 \\
\hline page r ange & $495-507$ \\
\hline year & $2009-10-01$ \\
\hline URL & ht t p: //hdl . handl e. net /2297/20401 \\
\hline
\end{tabular}




\section{Genetic deficiency of carnitine/organic cation transporter 2 (slc22a5) is associated with altered tissue distribution of its substrate pyrilamine in mice}

Sayaka Kato, Yukio Kato, Tadakatsu Nakamura, Tomoko Sugiura, Yoshiyuki Kubo, Yoshiharu Deguchi and Akira Tsuji

Division of Pharmaceutical Sciences, Graduate School of Natural Science and Technology, Kanazawa University, Kakuma-machi, Kanazawa 920-1192 (S.K., Y.K., T.N., T.S., Y.K., A.T.) and Department of Drug Disposition and Pharmacokinetics, School of Pharmaceutical Sciences, Teikyo University, 1091-1 Suarashi, Sagamiko, Sagamihara, Kanagawa 229-0195 (Y.D.), Japan.

This study was supported in part by a Grant-in-Aid for Scientific Research provided by the Ministry of Education, Science and Culture of Japan. 
RUNNING TITLE: Genetic deficiency of octn2 affects pyrilamine disposition

\section{Corresponding author :}

Prof. Akira Tsuji, Ph.D

Division of Pharmaceutical Sciences, Graduate School of Natural Science and

Technology, Kanazawa University, Kakuma, Kanazawa 920-1192, Japan

Tel:(81)-76-234-5085 / Fax:(81)-76-264-4010

Email: tsuji@kenroku.kanazawa-u.ac.jp 


\section{ABSTRACT}

Carnitine/organic cation transporter 2 (OCTN2) recognizes various cationic compounds as substrates in vitro, but information on its pharmacokinetic role in vivo is quite limited. Here we demonstrate altered tissue distribution of the OCTN2 substrate pyrilamine in juvenile visceral steatosis (jvs) mice, which have a hereditary defect of the octn2 gene. At 30 min after intravenous injection of pyrilamine, the tissue-to-plasma concentration ratio (Kp) in heart and pancreas was higher, whereas the Kp in kidney and testis was lower in jvs mice compared with wild-type mice. Pyrilamine transport studies in isolated heart slices confirmed higher accumulation, together with lower efflux, of pyrilamine in heart of jvs mice. The higher accumulation in heart slices of $j v s$ mice was abolished by lowering the temperature, by increasing the substrate concentration, and in the presence of other $\mathrm{H}_{1}$ antagonists or another OCTN2 substrate, carnitine, suggesting that OCTN2 extrudes pyrilamine from heart tissue. On the other hand, the lower distribution to the kidney of jvs mice was probably due to down-regulation of a basolateral transporter coupled with OCTN2, because, in jvs mice, (i) Kp in kidney of pyrilamine assessed immediately after intravenous injection ( 1 min) was also lower, (ii) urinary excretion of pyrilamine was lower, and (iii) uptake of pyrilamine in kidney slices was lower. The renal uptake of pyrilamine was saturable (Km $\sim 236 \mu \mathrm{M}$ ) and was strongly inhibited by cyproheptadine, astemizole, ebastine and 
terfenadine. The present study thus indicates that genetic deficiency of octn2 alters pyrilamine disposition tissue-dependently.

KEY WORDS: pharmacokinetics, pyrilamine, octn2, heart, kidney 


\section{INTRODUCTION}

Carnitine/organic cation transporter 2 (OCTN2/SLC22A5) was first isolated as a novel transporter with high homology to OCTN1/SLC22A4 [1,2]. The endogenous substrate of OCTN2 is a vitamin-like compound, carnitine, and deficiency of the OCTN2 gene leads to systematic carnitine deficiency (SCD) [3]. Carnitine is water-soluble, not membrane-permeable, and is required for ß-oxidation of fatty acids. In mammals, carnitine is supplied both by biosynthesis and from food intake.

Juvenile visceral steatosis (jvs) mouse, which has a mutation in the octn2 gene (Leu352Arg), was found to exhibit SCD-like symptoms, such as cardiac hypertrophy, lipid accumulation in the liver and hyperammonemia [3-6]. Several pharmacokinetic studies using jvs mice have revealed that OCTN2 governs carnitine disposition in vivo: ingested carnitine is absorbed in the small intestine via OCTN2, moved to circulating blood, and taken up by the liver and other organs via OCTN2 [7-9]. Because of its limited plasma protein binding, carnitine is easily filtered in the glomerulus, but is efficiently reabsorbed in the kidney via OCTN2 [7]. The putative role of OCTN2 in carnitine homeostasis is consistent with the localization of OCTN2 on apical membranes of epithelial cells in the small intestine and kidney $[9,10]$.

OCTN2 has also been reported to be involved in renal tubular secretion of tetraethylammonium (TEA), another OCTN2 substrate [11]. In addition to carnitine and TEA, 
OCTN2 also transports various cationic compounds including pyrilamine, quinidine and verapamil [12-14]. However, identification of OCTN2 substrates has been performed using OCTN2-transfected cell line systems in vitro, and the pharmacokinetic role of OCTN2 in vivo has still not been fully elucidated. Recently, Grigat et al. presented in vitro evidence that OCTN2 efficiently transports mildronate, though they considered that it is not a general drug transporter [15]. On the other hand, we have recently found that OCTN2 plays a major role in renal secretion of a $\beta$-lactam antibiotic, cephaloridine, using jvs mice [16].

Among OCTN2 substrates, pyrilamine is a member of the first-generation $\mathrm{H}_{1}$ antagonists, some of which, such as diphenhydramine and hydroxyzine, are widely used to treat allergic rhinitis and urticaria, despite their sedative side effect. The sedation is caused by their efficient distribution to the brain. In contrast to the first-generation compounds, second-generation $\mathrm{H}_{1}$ antihistamines cause less somnolence. In connection with this, transport mechanisms of antihistamines to the brain have been widely studied. One of the major transporters involved in the brain distribution of $\mathrm{H}_{1}$ antihistamines is P-glycoprotein (P-gp), the function of which as a drug efflux pump at the blood brain barrier (BBB) was originally clarified by Tsuji et al. using bovine primary cultured brain capillary endothelial cells [17], and subsequently confirmed in mdr1a gene knockout mice [18]. The permeability at the BBB of the nonsedative $\mathrm{H}_{1}$-antagonist ebastine and its metabolite carebastine was restricted by P-gp [19]. 
Chen et al. have also shown that P-gp reduces the brain's exposure to nonsedating second-generation, but not sedating first-generation, $\mathrm{H}_{1}$ antihistamines [20].

Other side effects provoked by certain $\mathrm{H}_{1}$ antagonists include cardiovascular toxicity. In particular, astemizole and terfenadine block rapid delayed rectifier $\mathrm{K}^{+}$current, leading to serious adverse events, such as QT prolongation [21, 22]. Occurrence of this side effect depends on the affinity of drug for the $\mathrm{K}^{+}$channel and on the drug concentration in cardiomyocytes. Therefore, it is necessary not only to clarify the interaction of drugs with the $\mathrm{K}^{+}$channel, but also to elucidate the membrane permeation mechanism of these drugs in the heart, since the latter may influence the unbound concentration of the drugs inside cardiomyocytes. However, only limited information is available on transporter functions in cardiomyocytes. Recently, Iwata et al. have proposed that OCTN2 is localized on the sarcolemma of cardiomyocytes and on the membrane in the intercalated disc, and suggested that it is involved in the influx of carnitine into the heart [23]. In the present study, we aimed to examine the possible involvement of OCTN2 in the distribution of pyrilamine to the heart and other organs, using jvs mice as a tool to clarify the role of OCTN2 in vivo. 


\section{MATERIALS AND METHODS}

\section{Materials and animals}

Pyrilamine was purchased from Sigma-Aldrich Japan K.K. (Tokyo, Japan). All other reagents were commercial products of reagent grade. Jvs mice, originally found among mice of the C3H.OH strain [24], and control (wild-type) C3H/HeJ mice (Japan SLC, Hamamatsu, Japan) were used. By mating heterozygous male and female mice, we obtained homozygous mutants (jvs/jvs) and wild-type mice. All the animal experiments were performed according to the Guidelines for the Care and Use of Laboratory Animals in Takara-machi Campus of Kanazawa University.

\section{Pharmacokinetic studies of pyrilamine in vivo}

Eight-week-old male mice were used after overnight starvation to study the disposition of pyrilamine. Mice were anesthetized with pentobarbital and injected with $3.75 \mathrm{mg} / \mathrm{kg}$ of pyrilamine via the right jugular vein as a bolus. Serial blood samples $(20 \mu \mathrm{L})$ were collected at designated time intervals from the right jugular vein of each mouse using heparinized capillary tubes. Urine samples were collected at designated times by washing the bladder with saline through polyethylene tubing (SP31, Natsume, Tokyo, Japan). For determination of tissue-to-plasma concentration ratio $(\mathrm{Kp})$, the mice were decapitated at 1 or $30 \mathrm{~min}$ after the 
intravenous injection. Tissues were quickly excised, rinsed well with ice-cold saline, blotted to dryness, weighed and stored at $-30^{\circ} \mathrm{C}$ until use.

\section{Uptake studies of pyrilamine in isolated heart and kidney slices}

Mice were sacrificed by decapitation under diethyl ether anesthesia. The heart and kidney were immediately excised and rinsed with about $50 \mathrm{~mL}$ of ice-cold saline. Atrium and connective tissues were carefully removed, and the heart was sectioned at $350 \mu \mathrm{m}$ with a microslicer (DTK-2000, Dosaka EM Co. Ltd., Kyoto, Japan). The kidney was sectioned by the same method. The slices were then soaked in ice-cold Krebs-Ringer bicarbonate buffer (KRB

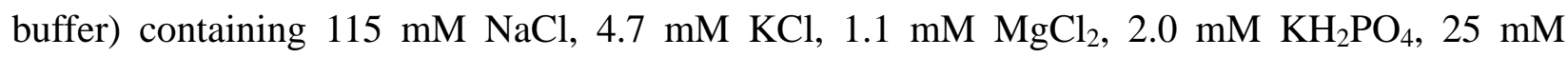
$\mathrm{NaHCO}_{3}, 2.5 \mathrm{mM} \mathrm{CaCl}_{2}$ and $11 \mathrm{mM}$ D-glucose. After 5 min pre-incubation, the heart and kidney slices were moved to KRB buffer containing $2 \mu \mathrm{M}$ pyrilamine prewarmed at $37^{\circ} \mathrm{C}$, with bubbling of $95 \% \mathrm{O}_{2} / 5 \% \mathrm{CO}_{2}$. This pyrilamine concentration $(2 \mu \mathrm{M})$ was set to be as lower as possible to avoid any saturation in transport systems, but also to be higher enough for the determination of pyrilamine in both tissue slices and medium using HPLC. At designated times, slices were picked up from the incubation buffer and rinsed with about $50 \mathrm{~mL}$ of ice-cold saline. They were blotted dry, weighed and stored at $-30^{\circ} \mathrm{C}$ until use.

In the inhibition experiments, inhibitors were also included in the KRB buffer. In the 
efflux experiments, the heart slices were first incubated in KRB buffer containing $2 \mu \mathrm{M}$ pyrilamine for 60 min, washed with ice-cold KRB buffer and then moved to KRB buffer prewarmed at $37^{\circ} \mathrm{C}$. At designated times, the slices were removed, washed with ice-cold $\mathrm{KRB}$ buffer, blotted dry, weighed and stored at $-30^{\circ} \mathrm{C}$ until the HPLC determination. Efflux transport activity was evaluated by measuring the pyrilamine content remained in the slices.

All the uptake values were expressed as slice-to-medium concentration (S/M) ratio per unit tissue weight ( $\mu \mathrm{L} / \mathrm{mg}$ tissue), obtained by dividing the amount of pyrilamine in the slices by the initial concentration in the medium and the weight of the slices.

\section{Measurement of blood-to-plasma concentration ratio and plasma protein binding}

Blood was taken from mice under pentobarbital anesthesia into heparinized tubes. A $500 \mu \mathrm{L}$ aliquot of blood was pre-incubated for $3 \mathrm{~min}$ at $37^{\circ} \mathrm{C}$, and then spiked with $10 \mu \mathrm{L}$ of drug solution. The mixture was incubated at $37^{\circ} \mathrm{C}$ for $30 \mathrm{~min}$, and an aliquot was taken for determination of blood concentration $\left(\mathrm{C}_{\mathrm{b}}\right)$. The plasma was separated by centrifugation of the residual mixture at $2,500 \mathrm{~g}$ at $20^{\circ} \mathrm{C}$ for $10 \mathrm{~min}$. An aliquot of plasma was then taken for the determination of total plasma concentration $\left(\mathrm{C}_{\mathrm{p}}\right)$. The remaining plasma was placed in an ultrafiltration apparatus (Centrifree, Amicon Inc., Beverly, MA) with a molecular mass cut-off of $13 \mathrm{kD}$ and centrifuged at 3,000 rpm (TOMY RL-100, Tokyo, Japan) for $10 \mathrm{~min}$. After 
centrifugation, the concentration in the filtrate was determined as unbound concentration $\left(\mathrm{C}_{\mathrm{u}}\right)$.

The blood-to-plasma concentration ratio $\left(\mathrm{R}_{\mathrm{b}}\right)$ was calculated by dividing $\mathrm{C}_{\mathrm{b}}$ by $\mathrm{C}_{\mathrm{p}}$. The free fraction of pyrilamine in plasma $\left(\mathrm{f}_{\mathrm{p}}\right)$ was calculated by dividing $\mathrm{C}_{\mathrm{u}}$ by $\mathrm{C}_{\mathrm{p}}$. All the binding was normalized with respect to the filter blank.

\section{Determination of pyrilamine}

The homogenized tissue samples, blood, plasma and urine were deproteinized with methanol and centrifuged at $10,000 \mathrm{~g}$ for $15 \mathrm{~min}$. The supernatant was subjected to HPLC. The HPLC analysis for pyrilamine was performed using COSMOSIL 5C 18 -MS- II (150 x $4.6 \mathrm{~mm})$ (Nacalai Tesque, Kyoto, Japan). The mobile phase consisted of methanol/10 mM formate buffer (pH 3.75) (33/67). The UV detector was operated at a wavelength of $244 \mathrm{~nm}$. Chlorpheniramine was used as an internal standard.

\section{Data analysis}

Kinetic parameters for uptake by tissue slices were obtained using nonlinear least-squares regression analysis [25] based on the following equation:

$v=\frac{V \max \times s}{K m+s}+K n s \times S$

where v, s, Vmax, $\mathrm{Km}$, and $\mathrm{K}_{\mathrm{ns}}$ represent the initial uptake velocity, substrate concentration, maximum uptake velocity, Michaelis constant and non-saturable uptake clearance, respectively. 
The selection of the equation was based on Akaike's Information Criterion.

\section{Statistical analysis}

Statistical analyses were performed by means of Student's $t$-test or ANOVA with Tukey’s post hoc comparison test for single and multiple comparisons, respectively. Differences were considered statistically significant at $p<0.05$. 


\section{RESULTS}

\section{Plasma concentration, urinary excretion and tissue distribution of pyrilamine in wild-type}

\section{and jvs mice}

After intravenous injection of pyrilamine, little difference was observed in plasma concentration profile between wild-type and jvs mice (Fig. 1a). Urinary excretion of pyrilamine in jvs mice was lower than that in wild-type mice (Fig. 1b). The fraction of the dose excreted into urine during 240 min after the injection was at most 2-6\% (Fig. 1b). It has been reported that $30-40 \%$ of the dose was recovered in urine following i.v. administration of $\left[{ }^{14} \mathrm{C}\right]$ pyrilamine within 24 hr, predominantly as a glucuronide metabolite, whereas urinary excretion of unchanged pyrilamine was less than $10 \%$ in rats [26]. The present study also indicated that renal excretion would be a minor elimination pathway for pyrilamine in mice (Fig. 1b). Due to quantification limit for pyrilamine by HPLC system in the present study, time course of plasma pyrilamine concentration could be chased until 120 min (Fig. 1a), and this was the reason for inconsistent time periods between plasma concentration and urinary excretion profiles (Fig. 1a, 1b).

On the other hand, at 30 min after intravenous injection, the Kp of pyrilamine in heart and pancreas was 1.8 and 1.5 times larger, respectively, in jvs mice compared with wild-type mice (Table 1). The Kp in the small intestine of jvs mice was also 3.8-fold higher than that in 
wild-type mice, although this difference was not statistically significant. The Kp values in kidney and testis of $j v s$ mice, on the other hand, were about 15 and $65 \%$ of those in wild-type mice (Table 1). Thus, the change in distribution of pyrilamine in jvs mice was tissue-dependent. The Kp values were also determined at $1 \mathrm{~min}$ after intravenous injection, and that in kidney of $j v s$ mice was again significantly lower than that in wild-type mice (Table 1). The Kp at $1 \mathrm{~min}$ after injection in heart of $j v s$ mice tended to be higher than that in wild-type mice, although this difference was not significant (Table 1). The values for plasma unbound fraction (fp) of pyrilamine in wild-type and $j v s$ mice were $0.685 \pm 0.093$ and $0.513 \pm 0.093$, whereas the values for blood-to-plasma concentration ratio $(\mathrm{Rb})$ were $1.66 \pm 0.11$ and $1.74 \pm 0.23$, respectively, showing no significant difference between the two strains.

\section{Influx and efflux of pyrilamine in isolated heart slices}

The difference in heart distribution between wild-type and jvs mice may be explained by differences in tissue binding, influx and/or efflux processes. To investigate the transport mechanism in detail, uptake studies using heart slices were performed. Accumulation of pyrilamine in heart slices at 10 min was similar in wild-type and jvs mice, whereas after 60 min, that in jvs mice was higher than that in wild-type mice (Fig. 2a). In addition, pyrilamine content remaining in the heart slices was determined after 60 min preincubation with pyrilamine in order 
to directly examine the efflux process from the heart. The amount of pyrilamine that remained in the heart slices of jvs mice was higher than that in heart slices of wild-type mice (Fig. 2b), suggesting that there is a difference in the efflux process between wild-type and jvs mice.

The larger accumulation (Fig. 2a) and lower efflux (Fig. 2b) in the heart slices of jvs mice may be explained by a decrease in efflux of pyrilamine from the heart of jvs mice. To investigate whether or not the difference between wild-type and jvs mice was due to a carrier-mediated system, we then examined the influence of an excess concentration (20 mM) of pyrilamine, carnitine, or $\mathrm{H}_{1}$ antagonists and of a lower temperature $\left(4^{\circ} \mathrm{C}\right)$. For this purpose, the accumulation of pyrilamine was determined after 120 min incubation, when the difference between wild-type and jvs mice was clear (Fig. 2a). Disappearance of the difference between the two strains in the presence of an inhibitor would suggest inhibition of the efflux process of pyrilamine, whereas a decrease in the absolute value of pyrilamine accumulation in the presence of the inhibitor would indicate inhibition of the influx process and/or tissue binding. The difference in the accumulation of pyrilamine was diminished at $4^{\circ} \mathrm{C}$. (Fig. 3a). At $20 \mathrm{mM}$ pyrilamine, the difference in accumulation between wild-type and jvs mice was reduced compared with the control ( $2 \mu \mathrm{M}$ pyrilamine), but there was still a significant difference (Fig. 3a). The absolute value of the pyrilamine accumulation was also reduced in both strains (Fig. 3a). The significant difference in pyrilamine accumulation between wild-type and jvs mice also 
disappeared in the presence of $20 \mathrm{mM}$ carnitine (Fig. 3a). The concentration of pyrilamine and carnitine (20 mM) was set as higher as possible so that saturation and/or inhibition can be observed in the pyrilamine accumulation (Fig. 3a). The osmotic control was not used in combination with this study, and it would be possible that the osmotic pressure may affect the membrane transporters. Next, we examined the influence of various antihistamines on the pyrilamine accumulation for 120 min in heart slices. Due to limited solubility, the concentration of ebastine, astemizol and terfenadine was set to be $50 \mu \mathrm{M}$, whereas the concentration of highly soluble diphenhydramine was set at $5 \mathrm{mM}$ (Fig. 3b). Diphenhydramine, promethazine, ebastine and carebastine also diminished the difference in pyrilamine accumulation between wild-type and jvs mice (Fig. 3b). Cyproheptadine, diphenhydramine and promethazine also decreased the absolute value of pyrilamine accumulation in both strains, whereas promethazine did not (Fig. 3b). The pyrilamine accumulation by heart slices of jvs mice was significantly different from that in wild-type mice even in the presence of cyproheptadine, astemizol, terfenadine and fexofenadine (Fig. 3b).

\section{Renal handling of pyrilamine in wild-type and jvs mice}

To investigate renal transport of pyrilamine, uptake studies were performed in isolated

kidney slices. Uptake of pyrilamine in kidney slices of wild-type mice gradually increased, 
whereas the increase in jvs mice was much smaller (Fig. 4a). The initial uptake of pyrilamine assessed in kidney slices of wild-type mice for $10 \mathrm{~min}$ was saturable (Fig. 4b), and kinetic analysis revealed saturable and unsaturable components with $\mathrm{Km}$ of $236 \pm 165 \mu \mathrm{M}$, Vmax of $1.62 \pm 0.96 \mathrm{nmol} / \mathrm{mg}$ tissue $/ 10 \mathrm{~min}$ and $\mathrm{K}_{\mathrm{ns}}$ of $1.91 \pm 0.40 \mu \mathrm{L} / \mathrm{mg}$ tissue $/ 10 \mathrm{~min}$.

Initial uptake of pyrilamine in kidney slices of wild-type mice was reduced to 15 and $34 \%$ of the control in the presence of $20 \mathrm{mM}$ pyrilamine and at $4^{\circ} \mathrm{C}$, respectively (Fig. 5a). The uptake after preincubation with ATP depletors (10 $\mathrm{mM} \mathrm{NaN}_{3}$ plus $10 \mathrm{mM} \mathrm{NaF}$ ) for 15 min was $64 \%$ of the control (Fig. 5a). Thus, the uptake is temperature- and energy-dependent. On the other hand, $1 \mathrm{mM}$ carnitine had only a minimal effect on pyrilamine uptake in kidney slices (Fig. 5a). To further characterize the influx process of pyrilamine, the effect of antihistamines was also examined in kidney slices. The pyrilamine uptake was significantly inhibited by diphenhydramine, cyptoheptadine, astemizole, ebastine, terfenadine and carebastine, but less so by fexofenadine (Fig. 5b). The effect of typical substrates of renal transporters on pyrilamine uptake was also examined, but tetraethylammonium (TEA), para-aminohippurate (PAH), benzylpenicillin (PCG) and digoxin minimally affected the pyrilamine uptake (Fig. 5c). 


\section{DISCUSSION}

Although many in vitro studies have indicated that OCTN2 is a drug transporter with broad substrate specificity, in vivo evidence of its role is quite limited. In the present study, we aimed to clarify the role of OCNT2 in the disposition of an $\mathrm{H}_{1}$ antagonist, pyrilamine, in vivo. When the tissue distribution of pyrilamine was compared between wild-type and jvs mice, the Kp values in heart and pancreas were found to be increased, whereas those in kidney and testis were decreased, as a result of the deficiency of octn2 gene (Table 1), although systemic exposure to pyrilamine was similar in the two strains (Fig. 1a). The jvs mice have a hereditary mutation in the octn2 gene, resulting in functional deficiency of the octn2 gene product [3-6]. Therefore, the present findings indicate that the tissue distribution of pyrilamine is influenced by octn2 gene deficiency. We have previously demonstrated that the Kp values of TEA in brain, lung, liver and spleen of jvs mice were lower than those in wild-type mice [11]. Similarly, the Kp values of carnitine was also lower in several organs of jvs mice [7]. Since TEA and carnitine are substrates of OCTN2 [11,12], and OCTN2 is ubiquitously expressed in many organs [27], OCTN2 may function as an influx transporter in these organs. Pyrilamine is also a substrate of OCTN2 [11,12], but the change in Kp values of pyrilamine associated with octn2 gene deficiency was different from those for TEA and carnitine, and was tissue-dependent. For example, the Kp of carnitine in heart and pancreas of jvs mice was lower than that in wild-type mice [7], whereas the Kp of 
pyrilamine in jvs mice was higher (Table 1). Therefore, the molecular mechanism(s) of the octn2 gene-associated change in tissue distribution of pyrilamine should be carefully considered.

The Kp value is generally affected by several kinetic parameters, including unbound fraction in plasma and tissues, and permeability clearance for influx and efflux processes. The unbound fraction in plasma of pyrilamine was similar in wild-type and jvs mice (see Results). Therefore, OCTN2 might be either directly or indirectly involved in tissue binding and/or membrane permeation. The Kp of pyrilamine in heart of jvs mice was significantly higher than that in wild-type mice 30 min after injection, but the difference was not so marked at 1 min after injection (Table 1). This result was confirmed in uptake studies with heart slices: the difference in pyrilamine accumulation in heart slices between wild-type and jvs mice was more marked at 60 min and later after the start of incubation (Fig. 2a). In addition, after preloading pyrilamine into heart slices, efflux of pyrilamine from the heart slices was delayed in jvs mice, compared with wild-type mice (Fig. 2b). These kinetic data obtained both in vivo and in vitro may suggest that OCTN2 functions as an efflux transporter for pyrilamine in heart. This hypothesis is further supported by the recent observation that OCTN2 is localized at plasma membrane of cardiac muscle cells in mice [23] and vascular endothelium in human heart [28]. In addition, the greater accumulation of pyrilamine in heart slices of jvs mice, compared with wild-type mice, was decreased or diminished in the presence of $20 \mathrm{mM}$ pyrilamine, carnitine or several $\mathrm{H}_{1}$ 
antihistamines (Fig. 3). The higher accumulation of pyrilamine in jvs mice was also diminished at $4^{\circ} \mathrm{C}$, at which active transport systems show minimal activity (Fig. 3a). These findings can also be explained if we consider the existence of an efflux transporter for pyrilamine which is saturable, sensitive to carnitine and several antihistamines, and temperature-dependent. However, the absolute values of pyrilamine accumulation were also decreased under various conditions (Fig. 3), and a possible effect on tissue binding and/or influx of pyrilamine cannot be excluded. In addition, carnitine failed to inhibit the pyrilamine accumulation in heart slices, whereas the difference of pyrilamine accumulation between wild-type and jvs mice was diminished in the presence of excessive carnitine (Fig. 3a). If we consider that carnitine is a good substrate for OCTN2, it would be possible that other unknown pyrilamine transporter than OCTN2 may play a role in the influx of pyrilamine.

Despite the previous observations indicating OCTN2-mediated transport of therapeutic agents in vitro [12-14], the present finding is the first to suggest the role of OCTN2 in drug disposition to the heart in vivo. There are quite few studies dealing with the pharmacokinetic role(s) of transporters in the heart in vivo. Zwart et al. demonstrated that distribution of MPP to the heart was decreased in organic cation transporter (OCT) 3 gene knockout mice, proposing that OCT3 is functionally expressed in heart as an influx transporter [29]. Higher levels of distribution to the heart of vinblastine and $\left[{ }^{14} \mathrm{C}\right]$ grepafloxacin in gene knockout mice for 
multidrug resistance protein 1 and multidrug resistance-associated protein (Mrp) 1, respectively, were also reported, suggesting that P-glycoprotein and Mrp1 function as efflux transporters in the heart [30,31]. In the present study, we also examined the effect of various $\mathrm{H}_{1}$ antihistamines on pyrilamine accumulation in heart slices (Fig. 3). Among $\mathrm{H}_{1}$ antagonists, diphenhydramine, promethadine, ebastine and carebastine diminished the difference in pyrilamine accumulation between wild-type and jvs mice (Fig. 3b), whereas astemizole and terfenadine, both of which are known to block rapid delayed rectifier $\mathrm{K}^{+}$current, leading to QT prolongation in the heart $[21,22]$, had minimal effects on pyrilamine accumulation (Fig. 3b). The efflux transporter would affect unbound drug concentration in the heart tissue, which is primarily important for $\mathrm{K}^{+}$channel inhibition. Therefore, further toxicological studies focusing on the role of OCTN2 and other transporters in the disposition of $\mathrm{H}_{1}$ antihistamines in heart are needed.

The mechanism of the difference in Kp value of the kidney between wild-type and jvs mice is likely to be more complicated. The lower Kp value in the kidney of jvs mice (Table 1) suggests that the reduction in urinary excretion in jvs mice (Fig. 1b) may be attributable to decreased uptake in renal epithelial cells. This hypothesis would be compatible with the present finding that a lower $\mathrm{Kp}$ value in $j v s$ mice was observed within a short period ( $1 \mathrm{~min})$ after pyrilamine injection (Table 1), and that the uptake of pyrilamine in isolated kidney slices of $j v s$ mice was also lower than that of wild-type mice (Fig. 4a). Thus, the uptake of pyrilamine, which 
presumably occurs at the basolateral membrane, was reduced in jvs mice. On the other hand, immunohistochemical study has revealed that OCTN2 is localized on the brush-border membrane of renal proximal cells [10]. Therefore, certain transporter(s) directly or indirectly associated with OCTN2 may be involved in pyrilamine uptake at the basolateral membrane. Uptake studies with kidney slices have shown that the pyrilamine transporter on the basolateral membrane is not influenced by inhibitors of known basolateral membrane transporters, such as OCTs, organic anion transporters and organic anion transporting polypeptides (Fig. 5c). The uptake transporter has high affinity for pyrilamine, with $\mathrm{Km}$ of $236 \mu \mathrm{M}$ (Fig. 4b), and is strongly inhibited by cyproheptadine, astemizole and ebastine (Fig. 5b), all of which mainly exist as cationic forms at physiological $\mathrm{pH}$. These characteristics are similar to those of the pyrilamine uptake system previously observed in brain capillary endothelial cells [32-35].

OCTN2 is localized on apical membranes of renal proximal tubules and involved in renal tubular secretion of TEA [11]. Our recent study has also revealed that cephaloridine is secreted into urine by OCTN2 [16]. Consequently, it is possible that OCTN2 is also involved in pyrilamine secretion at apical membrane of renal epithelial cells. However, reduction in both urinary excretion of pyrilamine and Kp value for kidney ( $1 \mathrm{~min})$ in jvs mice (Fig. 1b, Table 1) indicates that renal secretion of pyrilamine at apical membrane is not rate limiting step. Thus, the involvement of OCTN2 in pyrilamine secretion at apical membrane could not be demonstrated in 
the present study.

Pyrilamine is highly distributed to the brain (Kp value of $12 \sim 14$; Table 1 ). Although we could not demonstrate that OCTN2 is the pyrilamine transporter in the brain in the present study, the Kp value in the brain of jvs mice tended to be higher than that in wild-type mice (Table 1), suggesting that OCTN2 may be involved in pyrilamine distribution to the brain. Recently, Okura et al. have reported that oxycodone, a weak cationic drug and an opioid agonist used for treatment of moderate to severe cancer pain, is transported into the brain partially via the pyrilamine transporter [34]. Because these transporters presumably localized at the blood-brain barrier would affect unbound drug concentration inside the brain, it is essential to identify the pyrilamine transporter in order to understand the mechanism of sedation by $\mathrm{H}_{1}$ antagonists and the efficacy of drugs targeting the central nervous system.

Regarding the tissue distribution of carnitine, significant difference of its Kp values between wild-type and jvs mice was observed in many tissues, and this was compatible to expression profile of OCTN2 in ubiquitous tissues [7, 27]. In the present study, however, the alteration of pyrilamine Kp values in jvs mice was observed only in heart, pancreas, kidney and testis. This may be because other transporter(s) than OCTN2 would be involved in the tissue distribution of pyrilamine. We have previously reported that pyrilamine is efficiently taken up into brain via saturable transport system [32, 33, 35]. This “pyrilamine transporter” is probably 
different from OCTN2 because of to the difference in transport characteristics such as $\mathrm{Na}^{+}$- and $\mathrm{pH}$ dependency [34]. If the contribution of other transporter(s) to overall tissue distribution of pyrilamine is higher than that of OCTN2, the involvement of OCTN2 in tissue distribution of pyrilamine would not be observed, leading to discrepancy between the alteration of Kp values and expression of OCTN2. Therefore, OCTN2 would be one of the transporters involved in tissue distribution of pyrilamine. 


\section{CONCLUSION}

in vivo and in vitro pharmacokinetic studies revealed that OCTN2 is involved in

pyrilamine distribution to at least heart and kidney. This is the first evidence that OCTN2 may act as an efflux transporter for therapeutic agents in the heart in vivo. Further studies are needed to clarify the role of OCTN2 in the heart to understand its toxicological relevance, and jvs mice may be a helpful tool for this purpose. 


\section{ACKNOWLEDGEMENT}

We thank Ms Lica Ishida for technical assistance. 


\section{REFERENCE}

1 Wu X, Prasad PD, Leibach FH, Ganapathy V. cDNA sequence, transport function, and genomic organization of human OCTN2, a new member of the organic cation transporter family. Biochem Biophys Res Commun 1998; 246: 589-595.

2 Tamai I, Ohashi R, Nezu J, Yabuuchi H, Oku A, Shimane M, Sai Y, Tsuji A. Molecular and Functional Identification of Sodium Ion-dependent, High Affinity Human Carnitine Transporter OCTN2. J Biol Chem 1998; 273: 20378-20382.

3 Nezu J, Tamai I, Oku A, Ohashi R, Yabuuchi H, Hashimoto N, Nikaido H, Sai Y, Koizumi A, Shoji Y, Takada G, Matsuishi T, Yoshino M, Kato H, Ohura T, Tsujimoto G, Hayakawa J, Shimane M, Tsuji A. Primary systemic carnitine deficiency is caused by mutations in a gene encoding sodium ion-dependent carnitine transporter. Nat Genet 1999; 21: 91-94.

4 Hashimoto N, Suzuki F, Tamai I, Nikaido H, Kuwajima M, Hayakawa J, Tsuji A. Gene-dose effect on carnitine transport activity in embryonic fibroblasts of JVS mice as a model of human carnitine transporter deficiency. Biochem Pharmacol 1998; 55: 1729-1732.

5 Lu K, Nishimori H, Nakamura Y, Shima K, Kuwajima M. A missense mutation of mouse OCTN2, a sodium-dependent carnitine cotransporter, in the juvenile visceral steatosis mouse. Biochem Biophys Res Commun 1998; 252: 590-594.

6 Yokogawa K, Miya K, Tamai I, Higashi Y, Nomura M, Miyamoto K, Tsuji A. Characteristics of 
L-carnitine transport in cultured human hepatoma HLF cells. J Pharm Pharmacol 1999;

51: $935-940$

7 Yokogawa K, Higashi Y, Tamai I, Nomura M, Hashimoto N, Nikaido H, Hayakawa J, Miyamoto K, Tsuji A. Decreased tissue distribution of L-carnitine in juvenile visceral steatosis mice. J Pharmacol Exp Ther 1999; 289: 224-230.

8 Yokogawa K, Yonekawa M, Tamai I, Ohashi R, Tatsumi Y, Higashi Y, Nomura M, Hashimoto N, Nikaido H, Hayakawa J, Nezu J, Oku A, Shimane M, Miyamoto K, Tsuji A. Loss of wild-type carrier-mediated L-carnitine transport activity in hepatocytes of juvenile visceral steatosis mice. Hepatology 1999; 30: 997-1001

9 Kato Y, Sugiura M, Sugiura T, Wakayama T, Kubo Y, Kobayashi D, Sai Y, Tamai I, Iseki S, Tsuji A. Organic cation/carnitine transporter OCTN2 (Slc22a5) is responsible for carnitine transport across apical membranes of small intestinal epithelial cells in mouse. Mol Pharmacol 2006; 70: 829-83720

10 Tamai I, Nakanishi T, Kobayashi D, China K, Kosugi Y, Nezu J, Sai Y, Tsuji A. Involvement of OCTN1 (SLC22A4) in pH-Dependent Transport of Organic Cations. Mol Pharm 2003; 1: 57-66

11 Ohashi R, Tamai I, Nezu Ji J, Nikaido H, Hashimoto N, Oku A, Sai Y, Shimane M, Tsuji A. Molecular and physiological evidence for multifunctionality of carnitine/organic cation 
transporter OCTN2. Mol Pharmacol 2001; 59: 358-366.

12 Ohashi R, Tamai I, Yabuuchi H, Nezu JI, Oku A, Sai Y, Shimane M, Tsuji A. Na(+)-dependent carnitine transport by organic cation transporter (OCTN2): its pharmacological and toxicological relevance. J Pharmacol Exp Ther 1999; 291: 778-784.

13 Wu X, Huang W, Prasad PD, Seth P, Rajan DP, Leibach FH, Chen J, Conway SJ, Ganapathy V. Functional characteristics and tissue distribution pattern of organic cation transporter 2 (OCTN2), an organic cation/carnitine transporter. J Pharmacol Exp Ther 1999; 290: 1482-1492.

14 Ganapathy ME, Huang W, Rajan DP, Carter AL, Sugawara M, Iseki K, Leibach FH, Ganapathy V. bactam antibiotics as substrates for OCTN2, an organic cation/carnitine transporter. J Biol Chem 2000; 275: 1699-1707

15 Grigat S, Fork C, Bach M, Golz S, Geerts A, Schoming E and Grundemann D. The carnitine transporter SLC22A5 is not a general drug transporter, but it efficiently translocates mildronate. Drug Metab Dispos 2008; in press.

16 Kano T, Kato Y, Ito K, Ogihara T, Kubo Y, Tsuji A. Carnitine/organic cation transporter OCTN2 (Slc22a5) is responsible for renal secretion of cephaloridine in mice. Drug Metab Disops.2008; in press.

17 Tsuji A, Terasaki T, Takabatake Y, Tenda Y, Tamai I, Yamashima T, Moritani S, Tsuruo T, 
Yamashita J. P-glycoprotein as the drug efflux pump in primary cultured bovine brain capillary endothelial cells. Life Sci 1992; 51: 1427-1437.

18 Schinkel AH, Smit JJ, van Tellingen O, Beijnen JH, Wagenaar E, van Deemter L, Mol CA, van der Valk MA, Robanus-Maandag EC, te Riele HP. Disruption of the mouse mdr1a P-glycoprotein gene leads to a deficiency in the blood-brain barrier and to increased sensitivity to drugs. Cell 1994; 20: 491-502.

19 Tamai I, Kido Y, Yamashita J, Sai Y, Tsuji A. Blood-brain barrier transport of $\mathrm{H}_{1}$-antagonist ebastine and its metabolite carebastine. J Drug Target 2000; 8: 383-393.

20 Chen C, Hanson E, Watson JW, Lee JS. P-glycoprotein limits the brain penetration of nonsedating but not sedating $\mathrm{H}_{1}$-antagonists. Drug Metab Dispos 2003; 31: 312-318.

21 Mitcheson JS, Chen J, Lin M, Culberson C, Sanguinetti MC. A structural basis for drug-induced long QT syndrome. Proc Natl Acad Sci U S A. 2000; 97:12329-12333

22 García-Ferreiro RE, Kerschensteiner D, Major F, Monje F, Stühmer W, Pardo LA. Mechanism of block of hEag1 K+ channels by imipramine and astemizole. J Gen Physiol 2004; 124: 301-317.

23 Iwata D, Kato Y, Wakayama T, Sai Y, Kubo Y, Iseki S, Tsuji A. Involvement of carnitine/organic cation transporter OCTN2 (SLC22A5) in distribution of its substrate carnitine to the heart. Drug Metab Pharmacokinet 2008; 23:207-215 
24 Koizumi T, Nikaido H, Hayakawa J, Nonomura A, Yoneda T. Infantile disease with microvesicular fatty infiltration of viscera spontaneously occurring in the $\mathrm{C} 3 \mathrm{H}-\mathrm{H}-2(0)$ strain of mouse with similarities to Reye's syndrome. Lab Anim 1988; 22: 83-87

25 Yamaoka K, Tanigawara Y, Nakagawa T, and Uno T. A pharmacokinetic analysis program (MULTI) for microcomputer. J Pharmacobiodyn 1981; 4: 879 - 885.

26 Kelly DW, Slikker W Jr. The metabolism and elimination of pyrilamine maleate in the rat. Drug Metab Dispos 1987; 15: 460-465

27 Tamai I, Ohashi R, Nezu JI, Sai Y, Kobayashi D, Oku A, Shimane M, Tsuji A. Molecular and functional characterization of organic cation/carnitine transporter family in mice. J Biol Chem 2000; 275: 40064-40072.

28 Grube M, Meyer zu Schwabedissen HE, Präger D, Haney J, Möritz KU, Meissner K, Rosskopf D, Eckel L, Böhm M, Jedlitschky G, Kroemer HK. Uptake of cardiovascular drugs into the human heart: expression, regulation, and function of the carnitine transporter OCTN2 (SLC22A5). Circulation 2006; 113: 1114-1122.

29 Zwart R, Verhaagh S, Buitelaar M, Popp-Snijders C, Barlow DP Impaired activity of the extraneuronal monoamine transporter system known as uptake-2 in Orct3/Slc22a3-deficient mice. Mol Cell Biol 2001; 21: 4188-4196.

30 van Asperen J, Schinkel AH, Beijnen JH, Nooijen WJ, Borst P, van Tellingen O. Altered 
pharmacokinetics of vinblastine in Mdr1a P-glycoprotein-deficient Mice. J Natl Cancer Inst 1996; 88: 994-949

31 Sasabe H, Kato Y, Suzuki T, Itose M, Miyamoto G, Sugiyama Y. Differential involvement of multidrug resistance-associated protein 1 and P-glycoprotein in tissue distribution and excretion of grepafloxacin in mice. J Pharmacol Exp Ther 2004; 310: 648-655.

32 Yamazaki M, Fukuoka H, Nagata O, Kato H, Ito Y, Terasaki T, Tsuji A. Transport mechanism of an $\mathrm{H}_{1}$-antagonist at the blood-brain barrier: transport mechanism of mepyramine using the carotid injection technique. Biol Pharm Bull 1994; 17: 676-679.

33 Yamazaki M, Terasaki T, Yoshioka K, Nagata O, Kato H, Ito Y, Tsuji A. Carrier-mediated transport of $\mathrm{H}_{1}$-antagonist at the blood-brain barrier: a common transport system of $\mathrm{H}_{1}$-antagonists and lipophilic basic drugs. Pharm Res 1994; 11: 1516-1518

34 Okura T, Hattori A, Takano Y, Sato T, Hammarlund-Udenaes M, Terasaki T, Deguchi Y. Involvement of the Pyrilamine Transporter, a Putative Organic Cation Transporter, in Blood-Brain Barrier Transport of Oxycodone. Drug Metab Dispos 2008; 36: 2005-2013

35 Yamazaki M, Terasaki T, Yoshioka K, Nagata O, Kato H, Ito Y, Tsuji A. Carrier-mediated transport of $\mathrm{H}_{1}$-antagonist at the blood-brain barrier: mepyramine uptake into bovine brain capillary endothelial cells in primary monolayer cultures. Pharm Res 1994; 11: 975-978. 


\section{LEGENDS TO FIGURES}

\section{Figure 1}

\section{Plasma concentration (A) and cumulative urinary excretion (B) of pyrilamine}

Pyrilamine was intravenously administered at a dose of $3.75 \mathrm{mg} / \mathrm{kg}$ to wild-type (open circles) and jvs (closed circles) mice. Data are expressed as mean \pm S.E.M $(\mathrm{n}=3-8)$. Where an error bar is not shown, it is smaller than the symbol.

\section{Figure 2}

\section{Time-dependent uptake (A) and efflux (B) of pyrilamine in isolated heart slices}

(A) Uptake of pyrilamine in heart slices of wild-type (open circles) and jvs mice (closed circles) was measured during incubation with pyrilamine $(2 \mu \mathrm{M})$ at $37^{\circ} \mathrm{C}$. (B) Heart slices of wild-type (open circles) and jvs mice (closed circles) were pre-incubated with $2 \mu \mathrm{M}$ pyrilamine for 60 min, washed with ice-cold buffer, and incubated at $37^{\circ} \mathrm{C}$ in the absence of pyrilamine for the indicated periods. Data represent amount of pyrilamine remaining in the slices, normalized by the amount just after the pre-incubation, and are expressed as mean \pm S.E.M. $(n=3-4)$. Where an error bar is not shown, it is smaller than the symbol. ${ }^{*} p<0.05$

\section{Figure 3}


Effect of temperature, carnitine and antihistamines on accumulation of pyrilamine in isolated heart slices

(A) Accumulation of pyrilamine $(2 \mu \mathrm{M})$ in heart slices of wild-type (open bars) and jvs mice (closed bars) was measured at $37^{\circ} \mathrm{C}$ for $120 \mathrm{~min}$, at which time, the accumulated amount was close to the steady-state value (see Fig. 2), in the presence of $20 \mathrm{mM}$ pyrilamine or carnitine, or at $4^{\circ} \mathrm{C}$. (B) The accumulation of pyrilamine $(2 \mu \mathrm{M})$ in heart slices of wild-type (open bars) and jvs mice (closed bars) was measured for $120 \mathrm{~min}$ at $37^{\circ} \mathrm{C}$ in the presence or absence of antihistamines at designated concentrations. Data are expressed as mean \pm S.E.M. $(n=3-4)$.

Where an error bar is not shown, it is smaller than the symbol. ${ }^{*} p<0.05$

\section{Figure 4}

Time course (A) and concentration dependence (B) of the uptake of pyrilamine in isolated

\section{kidney slices}

(A) The uptake of pyrilamine $(2 \mu \mathrm{M})$ in kidney slices of wild-type (open circles) and jvs mice (closed circles) was measured at $37^{\circ} \mathrm{C}$. (B) The uptake of pyrilamine at various concentrations in kidney slices of wild-type mice was measured for $10 \mathrm{~min}$ at $37^{\circ} \mathrm{C}$. The pyrilamine concentrations were set to be $30,50,100,300,500,750,1000,3000,5000,10000$ and $20000 \mu \mathrm{M}$. Data are presented as an Eadie-Hofstee plot and expressed as mean \pm S.E.M. ( $n=3-4)$. Where an error bar 
is not shown, it is smaller than the symbol. ${ }^{*} p<0.05$

\section{Figure 5}

Effect of temperature and carnitine (A), transporter substrates (B) and antihistamines (C) on pyrilamine uptake in isolated kidney slices

Uptake of pyrilamine ( $2 \mu \mathrm{M})$ in kidney slices of wild-type mice was measured at $37^{\circ} \mathrm{C}$ for $10 \mathrm{~min}$ in the presence or absence of each compound at the designated concentration. In panel (A), the incubation was also performed at $4^{\circ}$ C. Data are expressed as mean \pm S.E.M. $(n=3-4)$. Where an error bar is not shown, it is smaller than the symbol. ${ }^{*} p<0.05$ 
Table 1

Values of tissue-to-plasma concentration ratio (Kp) of pyrilamine in wild-type and jvs mice ${ }^{a}$

\begin{tabular}{lcccc}
\hline & \multicolumn{3}{c}{ Wild-type } & jvs \\
\cline { 2 - 5 } & \multicolumn{7}{c}{$\mathrm{Kp}(30 \mathrm{~min})^{b}$} \\
\hline Brain & 11.8 & \pm 0.8 & $14.3 \pm 1.1$ \\
Fat & 7.11 & \pm 0.46 & $7.65 \pm 0.87$ \\
Heart & 6.01 & \pm 0.44 & $10.6 \pm 1.1^{d}$ \\
Intestine & $0.432 \pm 0.154$ & $1.68 \pm 0.82$ \\
Kidney & 88.2 & \pm 17.8 & $13.8 \pm 3.2^{d}$ \\
Pung & 24.7 & \pm 1.5 & $18.9 \pm 2.1$ \\
Spleen & 26.7 & \pm 1.0 & $40.7 \pm 6.9^{d}$ \\
Testis & 35.1 & \pm 2.8 & $32.4 \pm 4.8$ \\
\hline
\end{tabular}

\begin{tabular}{lllll}
\multicolumn{8}{c}{$\mathrm{Kp}(1 \mathrm{~min}){ }^{c}$} \\
\hline Heart & 34.1 & \pm 3.4 & $43.9 \pm 5.5$ \\
Kidney & 43.3 & \pm 4.6 & $24.4 \quad \pm 2.8^{d}$ \\
\hline
\end{tabular}

${ }^{a}$ Data were expressed as mean \pm S.E.M $(\mathrm{n}=4-6)$

${ }^{b}$ The Kp values were measured at 30 min after intravenous administration of pyrilamine at a dose of $3.75 \mathrm{mg} / \mathrm{kg}$.

${ }^{c}$ The Kp values were measured at 1 min after intravenous administration of pyrilamine at a dose of $3.75 \mathrm{mg} / \mathrm{kg}$.

${ }^{d}$ Significantly different from wild-type mice. $p<0.05$ 
(a)

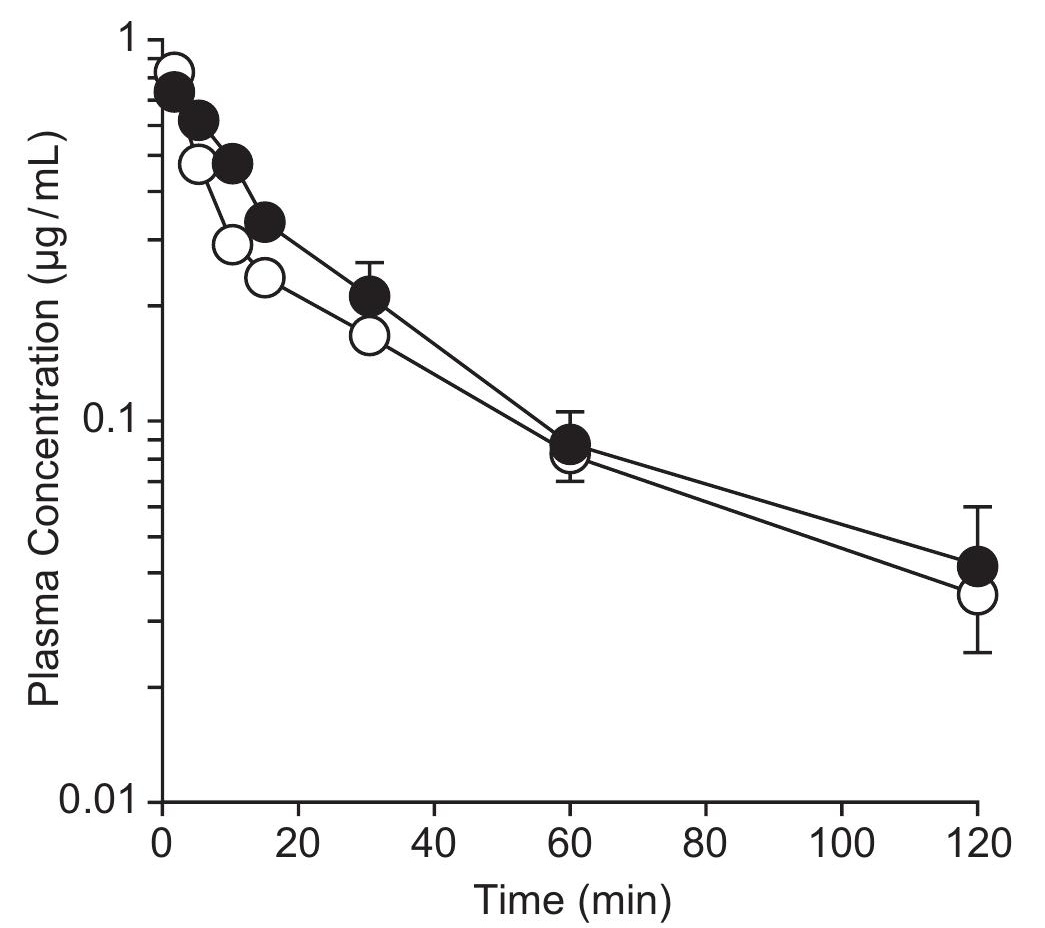


(b)

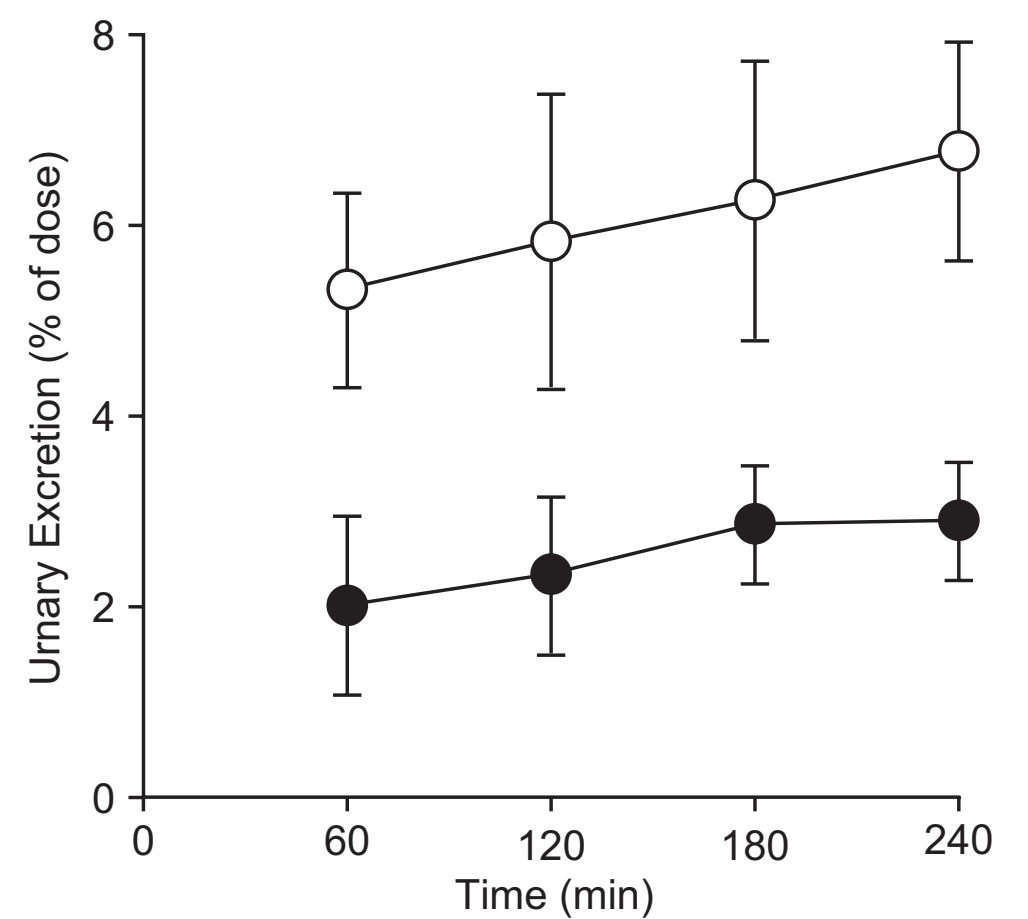




\section{(a)}

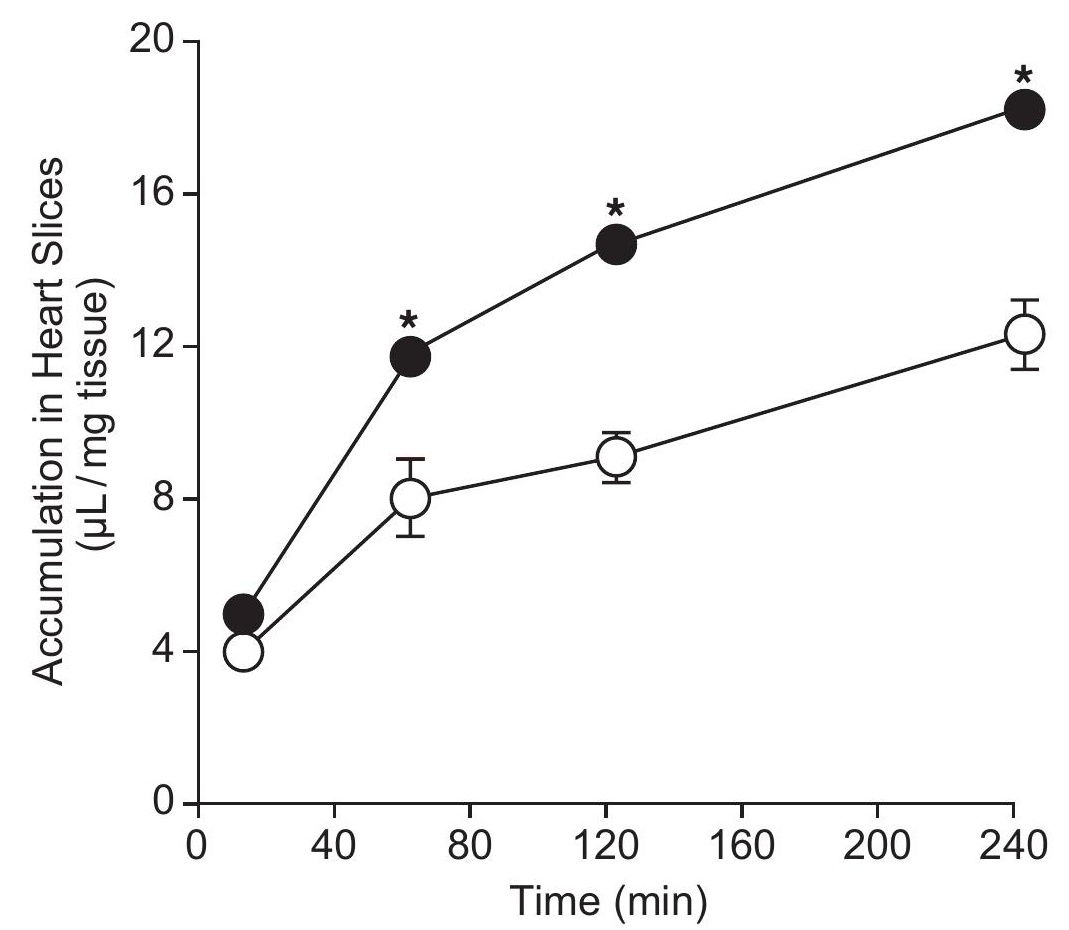


(b)

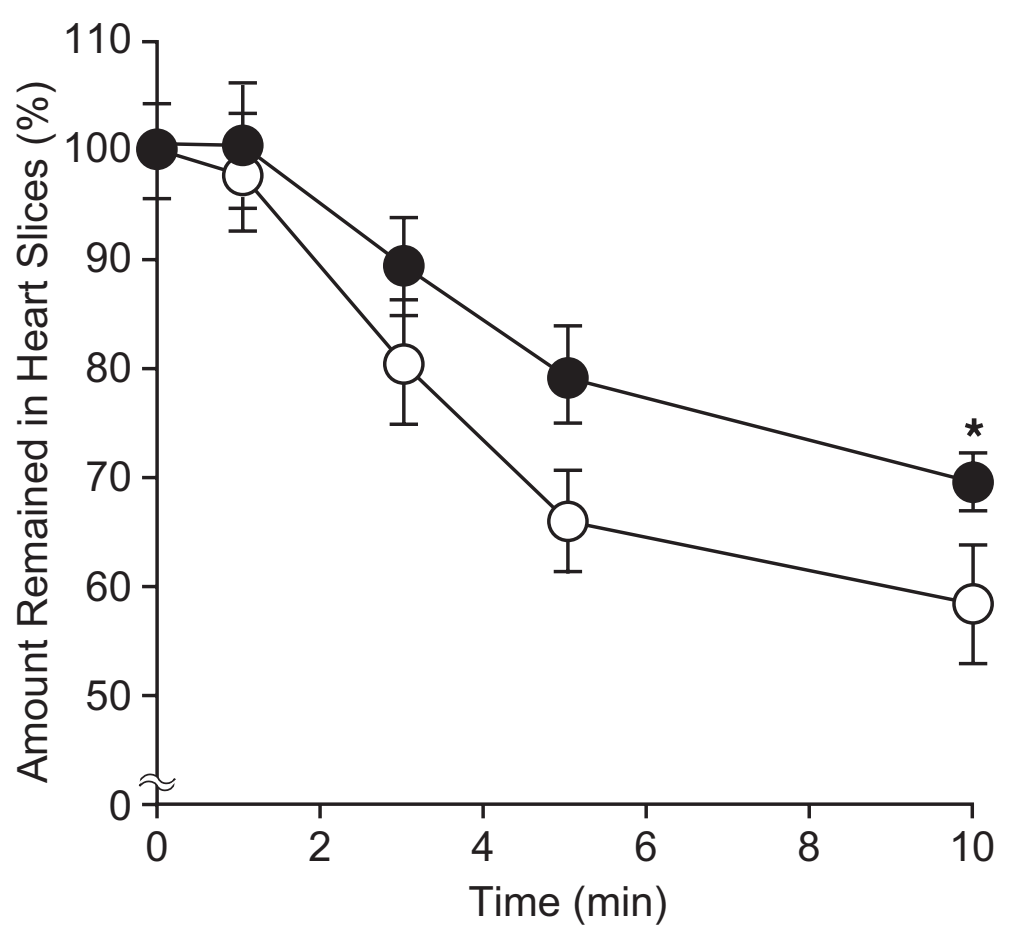


(a)

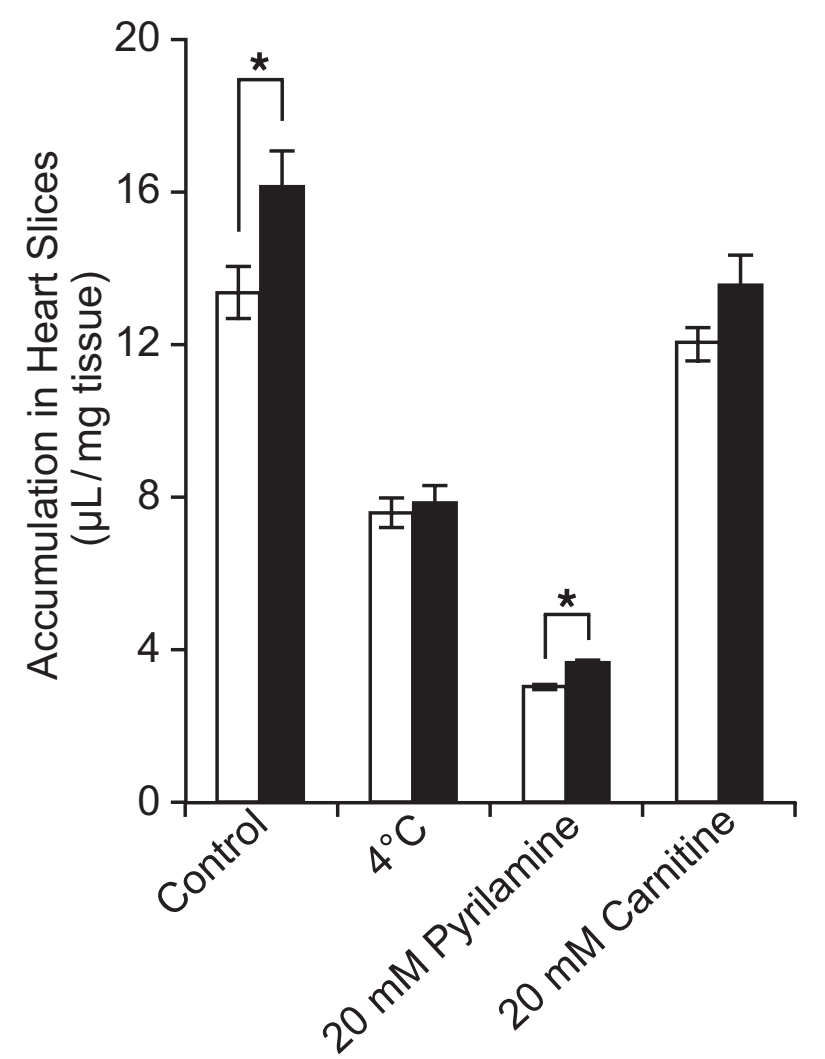


(b)

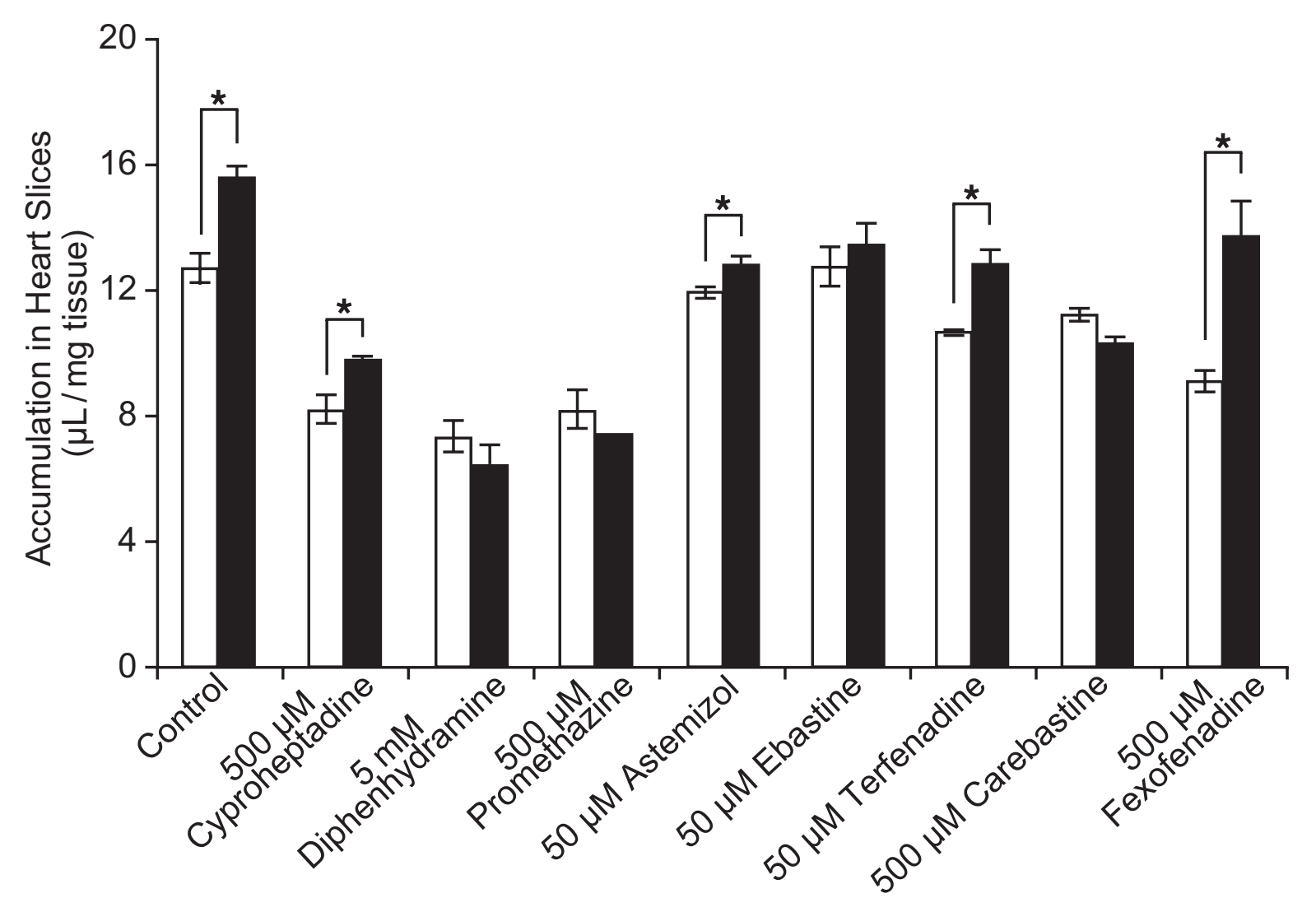


A

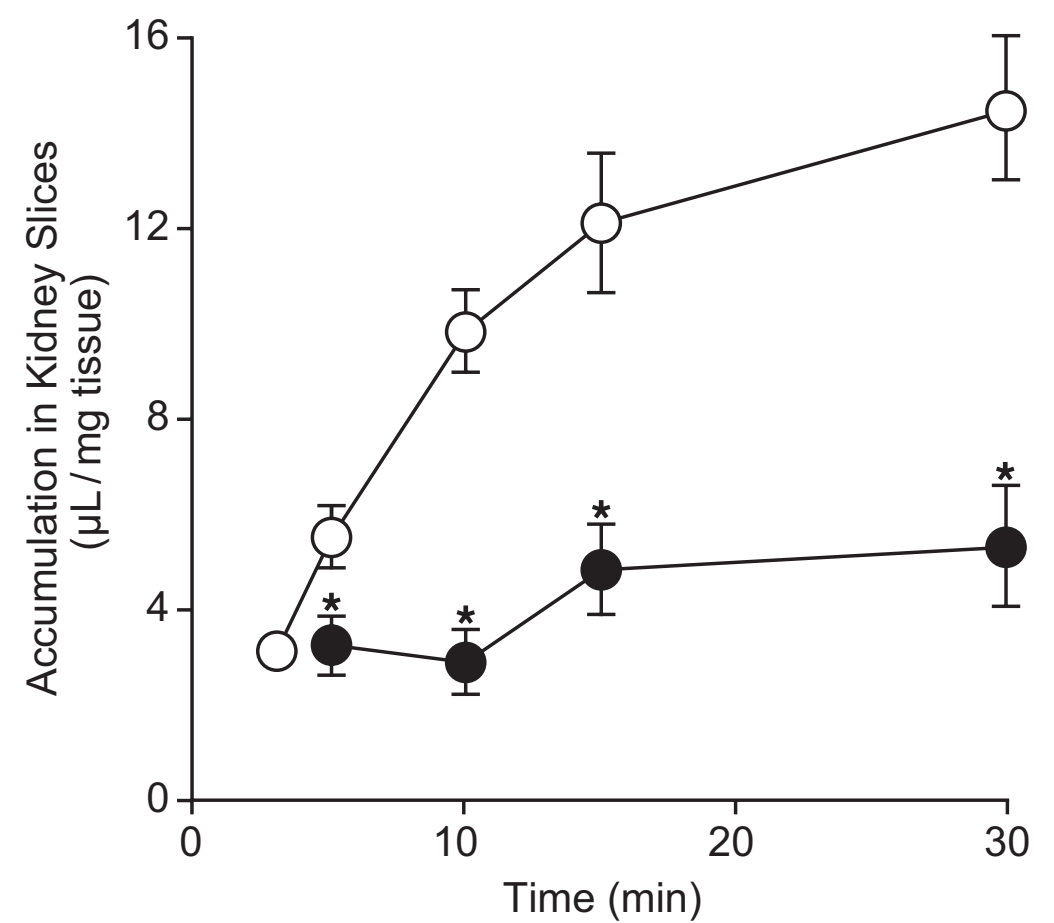




\section{(b)}

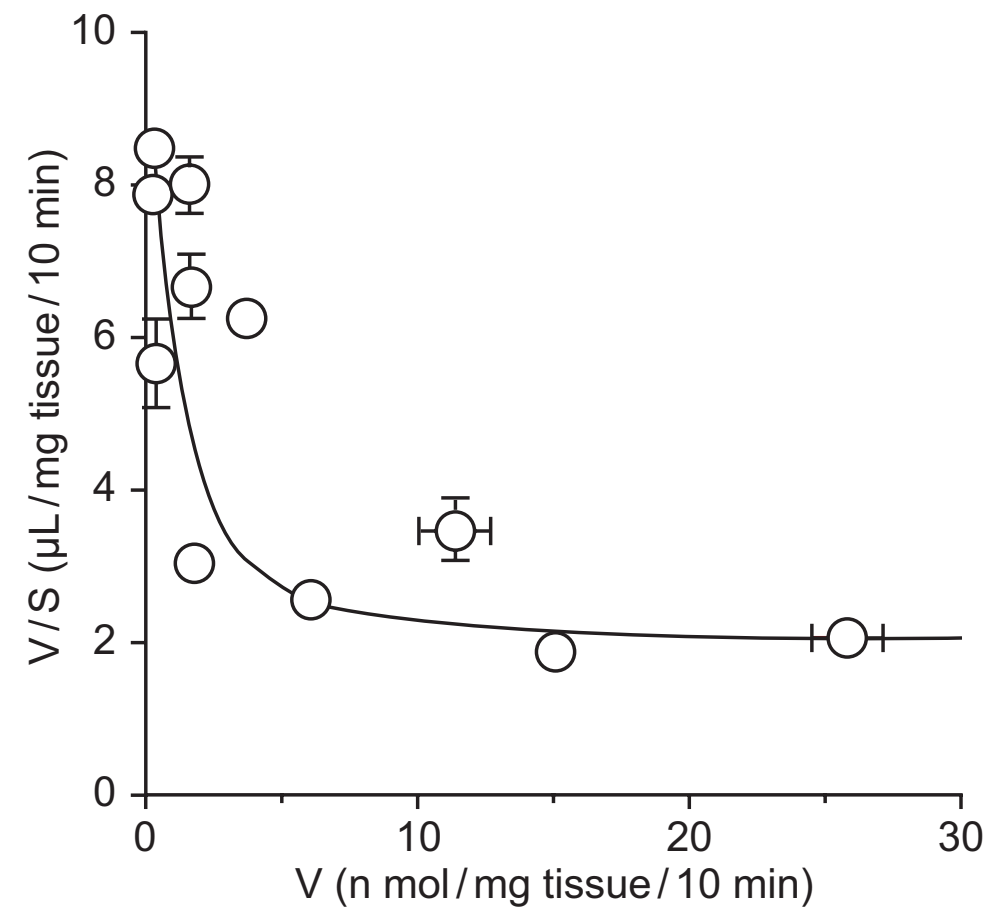




\section{(a)}

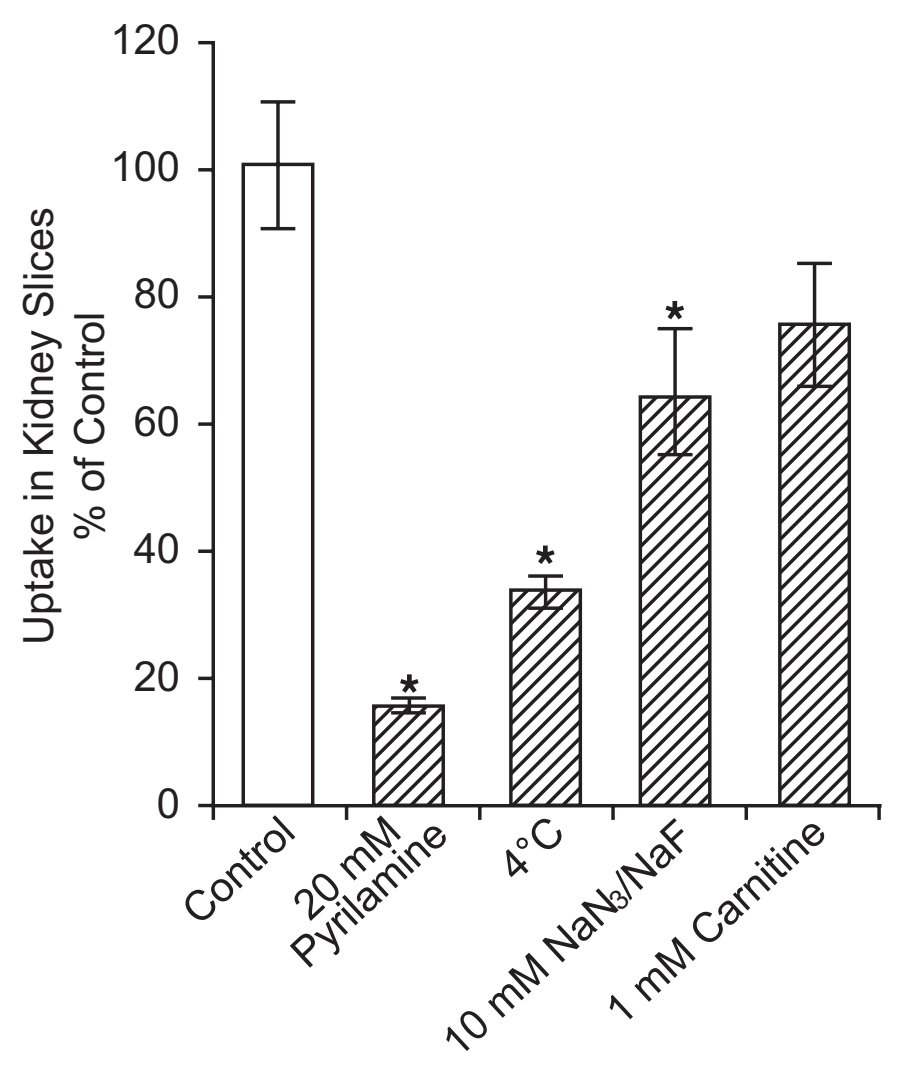


(b)

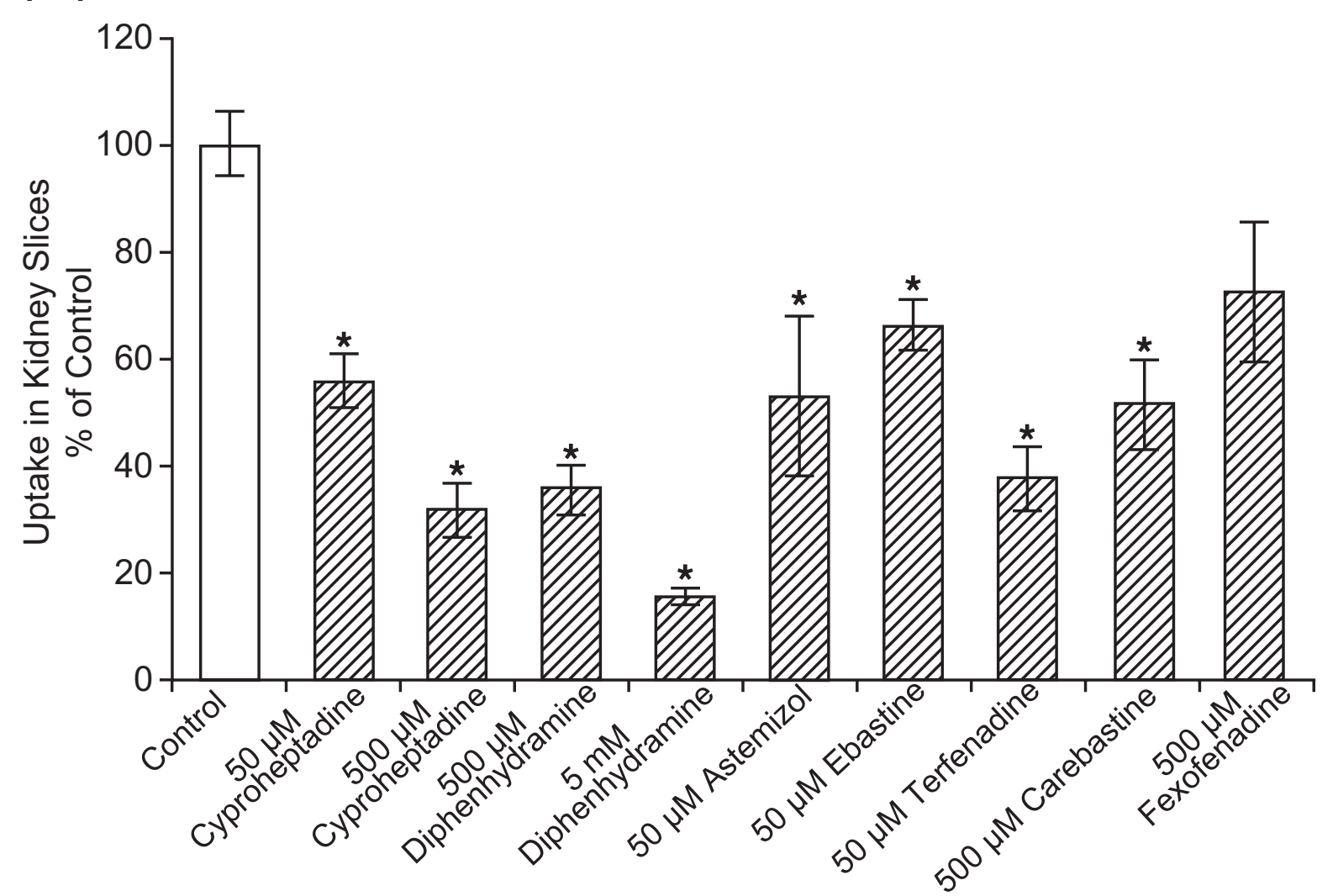

